Тюркан Олджай

Стамбульский университет

Литературоведческий факультет

Кафедра русского языка и литературы

turkanolcay@gmail.com
УДК $314.743(=161.1)(560)$

https://doi.org/10.18485/slavistika.2020.24.1.7

Оригинални научни рад примљено 31.03.2020.

прихваћено за штампу 21.05.2020.

\title{
БЕЛЫЕ РУССКИЕ В СТАМБУЛЕ
}

В этой работе исследуется социальная и культурная жизнь белоэмигрантов, которые, осев в Турции в 1920-х годах, создали свою диаспору. Основным источником исследования послужили издания того периода, государственные и частные архивы, пресс-архивы и архивы действующих в Стамбуле российских ассоциаций, а также мемуары десятков белых русских, проливающих свет на исследуемую тему.

Ключевые слова: Стамбул 1920-х годов, белые русские, русское зарубежье, эмиграция.

In this study the author analyzes the social and cultural life of Russian emigrants (so-called "White Russians"), who formed their own diaspora in Turkey in 1920s. The main sources of the research were books published during this period, documents from official and special archives (such as the press archives, archives of Russian associations active in Istanbul) and the memoirs of numerous of White Russians.

Keywords: Istanbul of 1920s, White Russians, Russia abroad, emigration.

Октябрьская революция 1917 г. в России и последовавшая за ней Гражданская война привели к тому, что сотни тысяч людей были вынуждены покинуть родину. Отправной точкой наиболее массовой эмиграции стало побережье Черного моря.

Стамбул (в то время Константинополь), сам переживавший период перемирия, оккупации войсками Антанты и Национальной освободительной войны, стал в то время единственно возможным портом назначения для перегруженных до отказа 126 кораблей вынужденных беженцев.

В первую очередь стоял насущный вопрос срочного рассредоточения российских изгнанников. Все раненые и больные были устроены в иностранных и русских госпиталях в районе Стамбула и плавучих. Инвалиды помещены во вновь открытые санатории и инвалидные дома. Около 60 тысяч чинов армии было отправлено, с сохранением военной организации и с оставлением части оружия, в особые военные лагеря, где им французским правительством был обеспечен паек; регулярные войска, свыше 25 тысяч, под начальством генерала от инфантерии Кутепова, - в Галлиполи, около 15 тысяч донцов, под начальством генерал-лейтенанта Абрамова, - в район Чаталджи и до 15 тысяч кубанцев, под начальством генерал-лейтенанта Фостикова, - на остров Лемнос. 32 тысячи беженцев были отправлены в различные государства, правительства которых дали согласие на их прием и обещали оказать им помощь: 22 тысячи в Сербию (в том числе 2 кадетских корпуса), 2 тысячи в Румынию, 4 тысячи в Болгарию и до 2 тысяч в Грецию. 30 судов русского военного флота, с личным составом до 6 тысяч человек, в том числе и морской кадетский корпус, по указанию правительства Франции, пошли в Бизерту (Macar O., Macar E. 2010; Bakar 
2012). Оставшихся белоэмигрантов стали расселять в городе и его окрестностях. Большая часть попала в беженские лагеря на европейской и азиатской сторонах, такие как Селимие, Сан-Стефано, Тузла, а также и на Принцевых островах. Некоторых разместили в пансионатах, других в монастырях, третьих в больницах и фабриках, часть ночевала на дворе Российского посольства или в полуразрушенных мазанках.

Несмотря на общие усилия русского командования, местных и союзнических администраций, благотворительных обществ и самих беженцев, пытавшиеся облегчить участь многотысячной эмигрантской массы, большинство людей находилось в бедственном положении. В поиске средств к существованию появились русские барахолки, где продавались привезенные с собой вещи. Кроме того, в газетах ежедневно появлялось множество объявлений о продаже драгоценностей, ковров, икон, моноклей.

Бо́льшая часть эмигрантов, продав все фамильные драгоценности и истратив все деньги, вынуждена была обдумывать свою дальнейшую судьбу. Однако шансы найти приличную работу в Стамбуле сводились к минимуму. Несмотря на чины, звания, высокий уровень образования и владение иностранными языками, русские брались за любую работу: становились плотниками, каменотесами, кузнецами, шоферами, поварами, официантами, портье, работали в аптеках, на телеграфе, рыбачили, плели рыболовные сети, изготовляли канаты, мастерили абажуры, детские игрушки, дамские сумочки. «Положение женщин», по воспоминаниям Александра Вертинского, «было лучше, чем мужчин» - они «привились. <..> Их охотно брали на всякие должности, мужчинам же найти работу было очень трудно. Мужчины устраивались главным образом при ресторанах; чистили картошку или ножи, мыли посуду. Почтенные генералы и полковники охотно шли на любую работу чуть ли не за тарелку борща <..>> (Вертинский 1990).

\section{Русские на «Бейоглу»}

Русские обживали в основном европейскую часть города на западном берегу Босфора, «Галата» (нынешний «Каракёй»), а также район «Бейоглу», сосредоточенный вокруг улицы «Пера», известная как Grand rue de Pera. На последней располагалось Посольство Российской империи, двор которого стал местом сбора эмигрантов и «напоминал собой пчелиный улей. <..> Сюда стекались со всех концов Константинополя..., чтобы узнать и послушать последние новости. Здесь были вывешены различные приказы, объявления, воззвания, списки и т.д.» (Слободской 1925). Через несколько домов находилось русское консульство, где помещалось и управление русского Красного Креста, а чуть далее - отдел пропаганды добровольческой армии - «Осваг». В узкой боковой уличке помещалась редакция Вечерней газеты под редакцией Б. В. Ратимова.

На Бейоглу располагалось также управление Всероссийского земского союза и союза городов. Здесь же функионировала первоначально русская почта, обслуживавшая беженцев. «Все эти учреждения были центральным нервом всей жизни беженцев в Константинополе. Если кто желал что нибудь узнать, 
навести справку, разыскать знакомого, найти или предложить работу, - все шли сюда со всех концов города» (Слободской 1925).

По словам очевидцев, 1920-1924 гг. были временем явного преобладания русских на «Бейоглу». Здесь русская речь слышалась чаще, чем турецкая. В. В. Шульгин замечает: «В летописях 1920-ый год будет отмечен, как год мирного завоевания Константинополя русскими» (Шульгин 1922). Подобную мысль высказывает и А. Н. Вертинский, выступавший в то время в своём кабаре «Черная роза»: «Константинополь стал очень быстро русифицироваться. На одной только рю-де-Пера замелькали десятки вывесок: ресторанов, кабаре (дансингов тогда еще не было), магазинов, контор, учреждений, врачей, адвокатов, аптек, булочных. < ..> Все это звало, кричало, расхваливая свой товар, напоминало о счастливых днях прошлого: “зернистая икра”, “филипповские пирожки”, “смирновская водка”, “украинский борщ” <...> » (Вертинский 1990).

Об этом вспоминает и бывший эмигрант А. Слободской: «В течение короткого времени вся набережная Галаты и Стамбула была усеяна всевозможными торговыми и агентурно-комиссионными конторами. Вся улица "Пера", начиная от тоннеля и кончая площадью Таксим, была занята торговыми предприятиями беженцев: мясными, колбасными, книжными магазинами, "кооперативами“ и бесконечным числом ресторанов. Немного ниже по улице "Тарля-Баши" русские промышленные предприятия: прачешные, пекарни и водочные заводы Кромского, Смирнова с сыновьями, Романенко. Зубровка, рябиновая, перцовка и пр. "настоящие русские водки“ заполнили собою все витрины греческих и русских магазинов и ресторанов» (Слободской 1925).

\section{Развлекательные заведения}

А вот как выглядела главная улица «Бейоглу» глазами Н. Н. Чебышева: «Пера, кривой коридор, по вечерам беспорядочно испещренный электрическими огнями, стала «нашей» улицей. Русские рестораны вырастали один за другим. Некоторые из них были великолепны, залы в два света, первоклассная кухня, оркестры, каких Константинополь никогда не слышал» (Чебышев 1933). Названия многочисленных вывесок ресторанов, кабаре и кондитерских: «Эрмитаж», «Петроград», «Большой Московский кружок», «Аркадия», «Карпыч», «Уголок», «Киевский» и т.д. напоминали старую, российскую жизнь. Здесь всё делалось на русский лад и в соответствии с русскими традициями. Всё излучало изысканность и благородство.

Главной притягательной силой русских развлекательных заведений была выступавшая в них гильдия артистов разных жанров - от классики до «казачка». Их высокий профессионализм и талант восхищали всех посетителей. Об этом свидетельствует и автор статьи «Beyaz Ruslar» (pyc. Белые русские) в İstanbul Ansiklopedisi Решад Экрем Кочу: «Белым русским принадлежит важное место в культурной истории Стамбула. Большинство из них выходцы из самых высоких и образованных кругов царской России... Первое, что они сделали, оказавшись в Стамбуле - создали развлекательные заведения, которых так не хватало большому городу. В открытых ими ресторанах, ночных клубах, кабаре турки увидели подлинное, освещенное благородством искусство» (Кос̧и 1961: 2625). 
Турецкую публику больше привлекал «легкий» жанр. С учетом этого предприниматель и солист Мариинского театра Владимир Петрович Смирнов открыл кабаре-театр «Паризиана». Так Стамбул стал родоначальником искусства русского эмигрантского кабаре. В популярном кабаре «Черная роза» выступал звезда эстрады Александр Вертинский. Турки, не понимая русских слов, буквально млели от его оригинальных интонаций. В том же кабаре выступали Юрий Морфесси и Елена Никитина. В «Пти Шане» пели шансонетки. В «Стелле» у московского негра-джазиста Фредерика Томаса играли русские музыканты и танцевали русские балерины. В одном из кабаре пела русские и цыганские песни А. И. Тараканова, выходившая на сцену в русском кокошнике. В другом кабаре цыганские романсы исполняла Анастасия Полякова. В зале «Каза д’Италия» с аншлагом проходили концерты трио Виктора Крюкова и его сестер Джеммы и Надежды, которые играли, пели и танцевали. Классические, народные и современные танцы в их исполнении имели большой успех. А на площадке парка «Гюльхане» выступал со своей труппой казачий офицер Михаил Турпаев (танцор Казбек) ${ }^{1}$.

Закрыв «Паризиану», В. П. Смирнов вместе с супругой, примадонной Мариинского театра, лирическим сопрано Валентиной Пионтковской организовал музыкальный театр «Буфф». Здесь под руководством режиссера А. Я. Любина они поставили оперетту Оффенбаха Прекрасная Елена, в которой приняли также участие Юрий Морфесси и опереточный комик Александр Полонский.

Русские обогатили Стамбул и своей национальной кухней. Особо популярными блюдами стали борщ, котлеты по-киевски, бефстроганов, солянка, пирожки с капустой, блинчики и водка всех сортов, в частности лимонная и «Смирновская». Изготовлением последней занялся вышеупомянутый оперный артист Владимир Смирнов, внук поставщиков этого продукта ко Двору российских императоров на протяжении 50 лет. Знаменитыми были кондитерские изделия кафе-кондитерской «Петроград» и утренние завтраки, состоявшие из ржаного хлеба, яйца всмятку, сливочного масла, швейцарского сыра и чая в тонких стаканах с подстаканниками. Но не только этим привлекало своих посетителей кафе «Петроград». Оно превратилось в место культурного времяпровождения не только для русских, но и для стамбульской элиты.

\section{Русская мода}

Вместе с вывесками русских врачей, адвокатов и мастеровых на «Бейоглу» стали появляться также ателье, обувные мастерские и косметические лаборатории. Из дневниковых записей Элен Арэль узнаем, что друг ее отца «офицер Николай Пьянковский после закрытия галлиполийского лагеря организовал косметическую лабораторию, одну из первых в стране, которая стала необычайно популярной» (цит. по Викторенко).

Модной новинкой Стамбула стали русские салоны верхнего платья и мехов.

1 Завоевавший известность как непревзойденный исполнитель горских танцев с кинжалами Михаил Турпаев дожил в Стамбуле до 98 лет и умер в 1978 г. 
Стройные, голубоглазые и светловолосые русские женщины (тогда их называли «карашо») производили ошеломляющее впечатление. Их модная одежда «представляла разительный контраст с обычной османской и считалась последним европейским писком в мусульманском Стамбуле» (там же). Русские «карашо» привнесли в Стамбул стиль последней европейской моды: непокрытая голова, короткая стрижка «колокол», тонкий шарф вокруг головы получил у турчанок название «Rus başı» («русская голова»), укороченные юбки клеш, на юбках кисточки из золотых нитей, пояса с бантом, стягивающие талию, расшитые жакеты (Deleon 2003: 32; Утургаури 2004: 278). Все они заняли место в журналах моды того времени.

О том, что волна стиля «карашо» коснулась и косметического сектора, свидетельствует газетная реклама, помещенная в газетах известным косметологом того времени Экремом Неджипом и начинавшаяся с вопроса «Почему так красива русская принцесса?».

Пляж «Флория», за счет белых русских приобрел новый вид - на место раздельных мужских и женских мест купания пришел общий пляж. Вместо прогулок по набережной Босфора становится модно ездить для прогулок и купания на Принцевы острова.

Русские познакомили стамбульчан и с лотошными клубами. Вот, что пишет об этом Чебышев: «Лото проникло всюду, даже туда, где держалась турецкая самобытность, и в угрюмый, чинный Стамбул. Появилось свыше 400 таких лотошных клубов. В среднем в день играло до 12 тысяч человек. < .. > Лото, около которого кормились несколько тысяч русских (в качестве служащих), закрыли 1 мая, а через два-три дня открыли тараканьи бега» (Чебышев 1933).

Однако при всем разнообразии новшеств, привнесенных эмигрантами из России, все же самое значительное влияние они оказали на городскую художественно-культурную жизнь (Олджай 2007, 2019).

Одним из таких событий стала открытая 9-го октября 1921-го года в Стамбуле первая выставка русских художников-эмигрантов, а спустя несколько месяцев и создание Союза русских художников с председателем Василием Ивановым.

\section{Русские художники в Стамбуле}

В галерее клуба «Маяк» на улице Бурса в доме № 40 до его закрытия в октябре 1922 г. были устроены еще семь экспозиций. Их постоянными участниками были Дмитрий Измайлович, Николай Сарафанов, Николай Перов и Николай Зарецкий. Иногда здесь выставлялись также работы Татьяны Алексинской, Константина Астори, Владимира Бобрицкого и др.

«Маяк» был не только художественной галереей, но одновременно и ресторанчиком, посетителями которого были преимущественно русские эмигранты. Кроме этого, он являлся также стамбульским центром Христианской ассоциации молодежи Южной России. Здесь устраивались литературные конференции, ставились маленькие пьесы русских авторов. В октябре 1922 г. «Маяк» был закрыт.

В то же время, усилиями управляющего Американским посольством Фостера Стэрнса и его супруги, была открыта художественная мастерская, а в ка- 
зарме «Мэкмахон» на Таксиме стала действовать еще одна художественная галерея. Здесь и в залах ҮМСА состоялись три выставки: 18 июня и 10 декабря 1922 г., 24 июня 1923 г. Все они, как и те, которые проходили в клубе «Маяк», были удостоены большого внимания прессы (Peyâm-ı Sabah. 17.06.1922; Vakit 17.06.1922; Vatan 25.06.1923).

Наряду с участием в сборных выставках, проводились также и авторские выставки. Так, например, выставка Н. Беккера, открывшаяся в залах фешенебельной гостиницы «Рега Palace» стала крупнейшим художественным событием 1922 года.

К 1924 г., с отъездом большинства художников, деятельность Союза русских художников прекратилась. Лишенные объединения, оставшиеся в городе художники были обречены на замкнутость и исполнение случайных, зачастую «рыночных» заказов. После ухода оккупационных сил выставок почти не бывало, интерес общества и печати постепенно угас. В городе окончательно обосновались Николай Калмыков (известный в Турции как Наджи Калмукоглу, 18961951), Ибрагим Сафиев (1998-1983), Николай Перов (1886-1963) и Николай Николаевич Якобсон (1895-1964).

Художественно-культурная жизнь белоэмигрантов не ограничивалось только вереницей красочных художественных выставок, которые собирали многие сотни посетителей. Важное место в стамбульской жизни эмигрантов занимала классическая музыка. Русские музыканты, а также целые русские оркестры выступали почти во всех ресторанах, кабаре и кинотеатрах Стамбула.

\section{Классическая музыка}

Без преувеличения можно сказать, что всей музыкальной жизнью Стамбула в первый год эвакуации руководили братья Слатины: Илья Ильич - пианист и дирижер, Владимир Ильич - скрипач, Александр Ильич - виолончелист. Под дирижерством И. И. Слатина в Стамбуле состоялся классический концерт, где впервые прозвучал «Реквием» Моцарта («На прощание» 1923: XLIX).

Среди приехавших в 1919 г. в Стамбул известных фигур «в первую очередь» нужно упомянуть профессора Московской консерватории по классу пианино Сергея Писанко-Романовского. Концерты его воспитанников, организовавшиеся раз в шесть месяцев, были одними из самых престижных выступлений в городе. Романовского называли «мелодраматическим поэтом классической музыки» (Бурнакин 1928).

Другим известным в то время профессором классической музыки был Алексанр Селиванов. В Стамбуле профессор Селиванов выступал как скрипач, музыкальный критик и преподаватель. При обучении своих учеников он применял оригинальную систему вокальной подготовки. Во время пребывания в Стамбуле им была издана книга Methode analytique Pour Placer La Voix (Методика постановки голоса) (Делеон 2003: 63).

Своей преподавательской деятельностью приобрела известность выпускница Московской консерватории Наталья Жило. В Стамбуле она выступила с теоретическими лекциями об искусстве выразительного пения, а ее система преподавания стала объектом стамбульской ежедневной газеты Le Journal d'Orient 
(Бурнакин 1928). Вместе с тем Жило слыла камерной концертной актрисой с богатым репертуаром русских песен и романсов.

Стамбульским культурным кругам были хорошо знакомы также имена талантливых дирижеров-скрипачей Павла Замуленко, Ивана Полянского и Христиана Лашенского. Все они обладали солидной музыкальной подготовкой и прославились в Стамбуле как дирижеры салонных оркестров в крупных фешенебельных отелях и кинотеатрах.

Среди прославившихся в Стамбуле дирижеров нужно упомянуть также имя Ивана Бутникова, который сразу же по приезде в город организует свой симфонический оркестр в составе 50 человек, исполнивший в Стамбуле в 1922 г. 45 концертов («На прощание» 1923: XLVIII). Бутников активно помогал при создании новой турецкой консерватории, при которой впервые открылись классы западной классической музыки и инструментов, а также в открытии русско-турецкой филармонии.

На турецкой сцене с большим успехом выступали также пианисты Владимир Дроздов и Павел Лунич, с редким мастерством исполнившие лучшие произведения Бетховена, Баха, Мендельсона, Шопена, Рахманинова, Гайдна, Дебюсси, Шумана и Листа. Самостоятельные фортепьянные концерты, данные Луничем в Стамбуле с 1920 по 1927 год, включали около ста пьес не только упомянутых композиторов, но и других корифеев своего времени.

Перечень русских музыкантов можно продолжить именами скрипачей-маэстро Михаила Голеско, Евгения Шведе, И. А. Вольпина, В. И. Поржицкого, С. Борицера и Н. Корсака, виолончелистов Ивана Онтчика и Александра Сулина, пианиста и начинающего композитора Константина Никольского, пианисток Марии Оболенской, А.М. Высоцкой и г-жи Воскобойниковой, дирижера Константина Стенгача, теоретиков музыки, профессоров Овтехаренко и Гартмана, а также В. И. Овчаренко, С. В. Петрова, В. А. Подгаецкого, Н.Н. Черепнина, Ф. Г. Гилоди, И. Фригмана, В. Заржицкого, А. Петровского и и многих других. Среди эмигрантов были также мастера русской балетной школы.

\section{Русская балетная и танцевальная школы}

Впервые познакомившаяся с классическим балетом, турецкая публика была глубоко впечатлена высоким мастерством замечательных русских мастеров. Джильберто Прими пишет в своих воспоминаниях, «что чувства, которые вызывали изящество и строгая красота русских балерин, не поддаются словесному выражению. < . .> Принеся на турецкую землю поэзию танца, они открыли туркам искусство балета не только классического, но и современного - модерн» («На прощание» 1923: XXXIX).

Первой встречей турецких зрителей с классическим балетом стали постановки на восточные мелодии Персидские ковры и Итальянская рапсодия на музыку Равеля в исполнении Василия Карнецкого. Карнецкий выступал также вместе с Мартой Крюгер в Голубом поезде, Вальпургиевой ночи и Шехерезаде, в постановке хореографов Зимина и Надеждина. Другим известным балетмейстером в Стамбуле был также Борис Князев. Спектакли оформлялись Павлом Челищевым. 
На сцене театра «Пти-Шань» в последующие три года космополитная публика увидела ряд русских балетных постановок, среди которых Лебединое озеро, Курильщики опиума, Волшебная флейта, Дон Жуан и др.

Вот что пишет о зимнем сезоне 1924-1925 гг. Месут Джемиль: «На протяжении всей зимы стамбульские ночи оживлялись Чайковским. Особенно красота так называемого “Танца гладиаторов” была у всех на устах. Балет Саломея был испещрен восточными звуками. Как будто древнеегипетские фрески ожили и явились в Стамбул. Нам никак нелегко вылить свои чувства на бумагу. Словами не описать изящество русского балета. Белые русские, вынужденные навсегда покинуть свою родину, подарили ночам Перы балет» (Cemil 1949: 73).

Весьма популярными также были выступления группы русских танцовщиков под руководством известного балетмейстера Петербургского Мариинского театра Евгении Воробьевой. Ей принадлежат постановки одноактных феерий и скэтчей Лесные тайны, Русский хоровод, Блан э нуар, Пляска Саломеи. Артисты исполняли не только балетную классику, но и русские народные, древнееврейские, египетские, арабские и испанские танцы. Пресса пестрела откликами о выступлениях, восхваляя рисунок танца, виртуозную технику, эмоциональную выразительность и владение драматургическими элементами.

Николаем Триполитовым и Ольгой Смирновой был создан дуэт «Смирнова и Триполитов», исполняющий эксцентрические балетные миниатюры и отличающийся сложными поддержками.

К концу 1920 г. большинство из танцовщиков уехало в Европу и Америку. Среди оставшихся в Стамбуле добились популярности Женя Нанасова, Купреянова и, особенно, выпускница Петербургского хореографического училища Лидия Красса Арзуманова (1897-1988), известная как Лейла Арзуман. Она является основателем первой балетной студии в Турции в конце 20-ых годов. Первое выступление ее участников состоялось в 1931-ом году в зале «Каза д’Италия». С постановкой балета Лесная сказка на музыку известного композитора Аднана Сайгуна в Анкаре в 1944-ом году, Арзуманова стала первым хореографом, осуществившим постановку балета на музыку турецкого композитора.

Выпускники Московской, Петербургской, Киевской и Тифлисской консерваторий способствавали усвоению турецкими музыкантами и танцовщиками произведений русской классики, расширив тем самым представление турецкой публики о мировой музыкальной культуре. Благодаря им на турецкой сцене впервые прозвучали творения русских композиторов Чайковского, Римского-Корсакова, Глазунова, Бородина и Стравинского. Профессионализм, творческие достижения русских музыкантов и артистов заложили основу той симпатии, которую турки и ныне питают к русскому музыкальному и балетному искусству.

Как писал русский судебный деятель, участник белого движения, журналист Николай Чебышев, Стамбул был «полон журналистами и литераторами, не успевшими ещё рассыпаться по вселенной» (Чебышев 1933). 


\section{Литературная и издательская деятельность}

Несмотря ни на временный и преходящий характер пребывания здесь, ни на трудности в материальном и моральном отношении, беженцы вели в Стамбуле организованную литературно-издательскую деятельность.

Первой формой литературного объединения в Стамбуле явился Цареградский цех поэтов, основанный летом 1920 г. по инициативе 17-летних поэтов Бориса Поплавского и Владимира Дукельского. А 3 января 1921 г. был учрежден Союз русских писателей и журналистов в Стамбуле.

В первые месяцы эмиграции увидели свет сборник стихов Андрея Аллина (наст. фам. Блюм) Солнечный итог (1920, 2-е изд. - в 1922), Стихи Ольги Ярославны (1920), сборники стихов Царь-Солнце Игоря Ястребцова (1920), Пасмурные птищы: Стихи 1918-1920 Григория Финна (1921) и Яичница с луком: Стихи, шаржи, напевы и перепевы Станислава Сарматова (С. Ф. Опеньховского) (1921).

Самым активным среди писателей, нашедших убежище в Стамбуле, был знаменитый сатирик, новеллист и драматург Аркадий Аверченко. Приехав в город 15 ноября 1920 г., Аверченко начал сотрудничать в ежедневной газете Presse du Soir, которую возглавляли Е. Максимов и О. Г. Зелюк. 4 декабря 1920 года газета начала публиковать цикл фельетонов Аверченко под заглавием Записки простодушного (в конце 1921 г. сборник выйдет в Стамбуле отдельным изданием). В 1922 г. вышли также его сборники рассказов Кипящий котел и Дети с приложением Руководства к рождению детей.

Другим популярным писателем был Борис Лазаревский - сын знаменитого украинского историка Александра М. Лазаревского. О его таланте можно судить по трехкратному изданию за год сборника рассказов Мое сердие. Душа женщинь (1920). Очередная повесть Лазаревского Вдова капитана, на 49 страниц была издана в том же 1920 году издательством «Верба». Одновременно было осуществлено и третье издание Моего сердия, на 60 страниц. Однако на обложке стоит год издания - 1921.

Помимо прозы издавалась и поэзия. В 1921 году издательством «Бабок и сыновья» были выпущены в свет Стихи Ольги Ярославны, на 39 страниц, а спустя два года там же появился и сборник стихотворений Лунный венок Ивана Корватского. В этих произведениях описывается бесподобная красота Стамбула и Босфора.

Иваном Корватским в 1927 г. были изданы сборник стихов Золотой рог и сборник рассказов Без ветрил. Будучи в то же время пианистом и преподавателем по классу пианино, Корватский писал для газет музыкальные обзоры и статьи о Стравинском.

Наряду с литературными произведениями в Стамбуле издавались еще учебники и словари, среди которых можно назвать Краткую грамматику и самоучитель турецкого языка (1921) тюрколога Г. Троценко. Наряду с фонетикой и грамматикой турецкого языка в нем имелись турецко-русский словарь «самых необходимых слов», тематический разговорник, образцы писем, популярные песни, басни и анекдоты. 
Все вышеперечисленные издания печатались в русских издательствах «Л. Бабок и сыновья», «Пресса», «Сфинкс», «За рубежом», «Русская мысль» и других.

При издательстве «Русская мысль», на площади Туннеля в доме № 2, имелись книжный магазин и библиотека, в которых читателям предлагался большой выбор: художественная литература, беллетристика, энциклопедии, учебники, самоучители, словари, разные русские ноты, а также открытки с видами русского ландшафта. Одновременно предлагались и русские заграничные газеты, и журналы.

Работали также книжные магазины «Культура» (1921-22), «Библиотека Пахалова» (1925), «Нацев», «Маршак», «Чернов», и «Забело». Эти магазины, помимо произведений русских авторов, изданных заграницей, заказывали и произведения мировой классики в русском переводе, а также выполняли функцию библиотек.

Стамбул оставался центром русской эмиграции первой волны до 1924 года, так и не став её постоянным центром. Пережив пору недолгого расцвета, русские эмигранты стали постепенно разъезжаться.

Исход русских из Стамбула был в известной степени продиктован тем обстоятельством, что пребывание русских эмигрантов совпало с разгаром в стране национально-освободительной революции во главе с Мустафой Кемалем (Ататюрком), который в какой-то мере сочувствовал идеям русской революции.

Прощаясь с Турцией, белоэмигранты выразили свою благодарность такими словами: «Спасибо Стамбул! Ты раскрыл нам свои объятия, приютил нас, дал нам работу, спас нам жизнь! Мы никогда не забудем тебя - город земной красоты! Мы были здесь как на своей второй родине. Когда мы сошли на берег с глазами полными слез и отчаяния, мы встретились в Турции с теплотой и дружелюбием. Наши турецкие друзья сделали все возможное, чтобы облегчить наши неутешные страдания. Это гостеприимная земля заключила нас в свои братские объятия и согрела нас своим теплом. Дав нам статус друзей, турецкий народ вплоть до героизма наилучшим образом доказал свои чувства. Мы, русские, еще никогда не видели столько доброты и щедрости. И поэтому примите, пожалуйста, наши дружеские благодарности и наши дружеские прощания» («На прощание» 1923: I-III).

К 1930 г. в Стамбуле осталось лишь 1400 русских. «Нас осталась лишь крохотная горсточка, - говорит Элен Арэль. - Сегодня о русской колонии напоминают только ресторан "Режанс" да еще православная церковь с Русским подворьем в Галате» (цит. по Викторенко).

Послесловием ко всему изложенному могли бы послужить слова Александра Вертинского: «Русские легко осваиваются повсюду. У нас есть какое-то исключительное умение обживать чужие страны, ибо, куда бы мы ни приехали, ... всюду мы приносили много своего, русского, только нам одним свойственного, так разукрашивали своим бытом быт чужой, что часто казалось, будто не мы приехали к ним, а они - к нам» (Вертинский 1990). 


\section{Использованная литература}

Викторенко, Алёна. «Призраки голого поля», Международный благотворительный фонд им. Генерала А. П. Кутепова <http://www.fund-kutepov.narod.ru/prizraki. $\mathrm{htm}>22.03 .2020$.

[Viktorenko, Алёna. «Prizraki gologo poliâ», Mezdunarodnyı̆ blagotvoritel'ny̌̆ fond im. Generala A. P. Kutepova <http://www.fund-kutepov.narod.ru/prizraki.htm> 22.03.2020]

Олджай, Тюркан. «Вклад русской диаспоры в культурную жизнь Стамбула» [В:] Т. Чакърова (ред.) Инновации исследования русского языка, литературы и культуры. Том I. Пловдив: Университетско издателство “П. Хилендарски", 2007, 453-465.

[Oldzhă, Tiurkan. «Vklad russkoǐ diaspory v kul'turnuiu zhizn Stambula» (V:) T. Chak"rova (red.) Innovatsii issledovaniâ russkogo iâzyka, literatury i kul'tury. Tom I. Plovdiv: Universitetsko izdatelstvo "P. Hilendarski", 2007, 453-465]

Олджай, Тюркан. «Штрихи культурной жизни русской эмиграции в Стамбуле (1919-1929)» [В:] Т. Олджай (отв. ред.) Русская белая эмиграция в Турции век спустя. Москва: ДРЗ, 2019, 153-193.

[Oldzhă, Tiurkan. «Shtrihi kul'turnoĭ zhizni russkor émigratsii v Stambule» (V:) T. Oldzhaĭ (otv. red.) Russkaiâ émigratsiiâ v Turtsii vek spustiâ. Moskva: DRZ, 2019, 153-193]

Помаренцев, И. «Правда о турецких банях». Литературно-художественный журнал Заповедник 25, 2001: 2-3.

[Pomarantsev, I. «Pravda o turetskih baniâh». Literaturno-hudozhestvennyı̌ zhurnal Zapovednik 25, 2001: 2-3]

Утургаури, Светлана Н. Белые русские на Босфоре 1919-1929. Москва: Институт Востоковедения РАН, 2013.

[Uturgauri, Svetlana N. Belye russkie na Bosfore 1919-1929. Moskva: Institut Vostokovedeniiâ RAN, 2013]

Bakar, B. Esir Şehrin Misafirleri: Beyaz Ruslar. İstanbul: Tarihçi Kitabevi, 2012.

Cemil, M. «Bale Tarihi». Radyo 86, 1949: 67-72.

Davis, Claflin C. İstanbul'da Mültecilerin Durumu. [B:] (C. R. Johnson M.А. ред.) İstanbul 1920. İstanbul: Tarih Vakfı Yurt Yayınları, 1995, 175-195.

Deleon, J. Beyoğlu'nda Beyaz Ruslar. İstanbul: Remzi, 2003.

Dumesnil, V. İşgal İstanbul'u. İstanbul: İstanbul Kitaplığı, 1993.

Koçu, Reşat Ekrem. «Beyaz Ruslar». [B:] (R. Е. Кос̧u ред.) İstanbul Ansiklopedisi. T. 5. İstanbul: Koçu Yayınları, 1961, 2523-2526.

\section{Источники}

Бурнакин, Анатолий А. Русские на Босфоре. Стамбул, 1928.

[Burnakin, Anatoliiǐ A. Russkie na Bosfore. Stambul, 1928]

Вертинский, Александр Н. Дорога длинною. Москва: Правда, <https://royallib.com/ book/vertinskiyaleksandr/dorogoy_dlinnoyu.html $>22.03 .2020$.

[Vertinskiiī, Aleksandr N. Doroga dlinnoiu. Moskva: Pravda <https://royallib.com/book/ vertinskiyaleksandr/dorogoy_dlinnoyu.html $>22.03 .2020]$ 
На прощание 1920-1923. (А. А. Бурнакин, Д. Валери и др. ред.) Константинополь: Бабок и сыновья, 1923.

[Na proshchanie 1920-1923. (А. A. Burnakin, D. Valeri и dr. red.) Konstantinolpl': Babok i synov'iâ, 1923]

Слободской, А. Среди эмиграции. Мои воспоминания. Киев-Константинополь 1918-1920. Харьков: Пролетарий, 1925. <https://knigogid.ru/books/1155991-srediemigracii> 22.02.2020.

[Slobodskoiǐ, A. Sredi émigratsii. Moi vospominaniiâ. Kiev-Konstantinopol' 1918-1920. Har'kov: Proletariilı, 1925. <https://knigogid.ru/books/1155991-sredi-emigracii> 22.02.2020]

Чебышев, Н. Н. Близкая даль. Париж, 1933. <http://www.dk1868.ru/history/chebishev. htm $>22.02 .2020$.

[Chebyshev, N. N. Blizkaiâ dal'. Parizh, 1933. <http://www.dk1868.ru/history/chebishev. htm $>22.02 .2020]$

Шульгин, В.В. Очерки. Москва: Гиз, 1922. <http://militera.lib.ru/memo/russian/ shulgin_vv/20.html $>22.02 .2020$.

[Shulgin, V. V. Ocherki. Moskva: Giz, 1922. <http://militera.lib.ru/memo/russian/ shulgin_vv/20.html $>22.02 .2020]$

\section{Туркан Олџај}

\section{БЕЛИ РУСИ У ИСТАМБУЛУ}

\section{Резиме}

Октобарска револуција 1917. године у Русији, као и грађански рат до ког је дошло након ње, приморали су стотине хиљада људи да напусте своју домовину. Полазна тачка најмасовније емиграције било је црноморско приморје, док је место одредишта био Истамбул (тада Константинопољ). У новембру 1920. године истамбулске улице биле су преплављене хиљадама руских емиграната.

Без обзира на емигрантски хаос који је владао, Руси су показали завидну способност за самоорганизацију и активан уметнички рад. „Руска експанзија“, ако тако можемо рећи, развијала се у два правца - свакодневном и културном - који су се међусобно преплитали, те их је временом било тешко раздвојити. Са једне стране, емигранти су отварали апотеке и посластичарнице, ресторане и кабарее, продавнице, мајсторске радње, руске салоне за продају хаљина и крзна, а са друге, претворили су Истамбул у центар руске културе који је обиловао богатим садржајима. Устаљени ток живота у граду и његову затвореност почели су да красе симфонијска, камерна и оперна музика, балетске представе које су се приказивале, изложбе које су се отварале...

У овом раду направљен је покушај истраживања социјалног и културног живота белих емиграната који су досељавањем у Турску двадесетих година XX века формирали своју дијаспору. Као основни извор за истраживање послужила су издања тога периода, државне и приватне архиве, као и новинске архиве и архиве акивних руских удружења у Истамбулу, као и мемоари десетине белих Руса који су значајно допринели расветљавању дате теме.

Кључне речи: Истамбул двадесетих година XX века, Бели Руси, руска дијаспора, емиграција. 